九州大学学術情報リポジトリ

Kyushu University Institutional Repository

Studies on the multiplication of OP 1 phage (Xanthomonas oryzae bacteriophage). 2 : Interference phenomena in the multiplication between $0 P_{-} 1$ and $O P \_1 \mathrm{t}$, the growth temperature mutant obtained from OP 1

Wakimoto, Satoshi

Laboratory of Plant Pathology, Department of Agriculture, Kyushu University

Yoshii, Hazime

Laboratory of Plant Pathology, Department of Agriculture, Kyushu University

https://doi.org/10.5109/22674

出版情報：九州大学大学院農学研究院紀要. 11 (1)，pp.53-61，1957-08. Kyushu University バージョン：

権利関係 : 
Journal of the Faculty of Agriculture, Kyūshii University, Vol. 11, No. I

August 30, 1957

\section{Studies on the multiplication of $\mathrm{OP}_{1}$ phage (Xanthomonas oryzae bacteriophage). 2}

Interference phenomena in the multiplication between $\mathrm{OP}$, and $\mathrm{OP}_{1 !}$, the growth temperature mutant obtained from $\mathrm{OP}_{1}{ }^{*}$

\section{Satosil Wakimoto and Hazime YoshiI}

\section{INTRODUCTION}

The multiplication of bacteriophage starts by the injection of the contents-desoxyribonucleic acid-of the phage adsorbed on the surface of the host cell. The penetrated DNA from the parent phage plays in the cell the principal role of the reproduction of new phages as the genetic marker.

When a bacterial cell is infected by two kinds of the virulent phages, the interference phenomena between the phages will take place. Phages are classified as the related with each other or as the unrelated on the standpoint of their serological reaction and morphological relationship. And the interference phenomena between two phages are different in accordance to their mutual relationships.

In the case of the unrelated phages, as it is reported with $E$ scherichia coli phage $\alpha(\mathrm{T} 1), \delta(\mathrm{T} 7)$ and $\gamma(\mathrm{T} 2)$, the mutual exclusion phenomena and depressor effect have taken place. ${ }^{5,6)}$ Nameiy, in the case of simultaneous infection of two unrelated phages, the contents of one of the two phages penetrate and multiply, while the other phage cannot self-reproduce due to the exclusion of the previously penetrated phage. The excluded phage which adsorbed on the cell surface, in its turn, interferes or depresses the multiplication of the intruded phage.

In the case of the related phages, both two phages penetrate and multiply without any interference between them, if they simultaneously attack the same host cell. In the progenies, besides the reproduction

* Contribution from the Laboratory of Plant Pathology. 
of normal phages of the characters of the respective parents, are produced the recombinants having the characters of both two parents as the results of recombination of the parent characters. When infection is unsimultaneous, lapse of time necessary for the excluding action of the prior phage against the succeeding phage is determined by the nature of the former. Interference phenomena of related phages were detailed in the experiments with $T$-even phages by Dulbecco. ${ }^{8,9}$

The authors isolated a mutant $\mathrm{OP}_{\mathrm{t}}$, phage--which differs in its optimum growth temperature from the wild type $\mathrm{OP}_{1}$ (Xanthomonas oryzae phage). Many kinds of phage mutant such as host range mutant,,$^{, 13)}$ plaque morphology mutant, ${ }^{7,12)}$ adsorption cofactor mutant, ${ }^{3 ;}$ proflavine resistant mutant, ${ }^{11}$ and heat resistant mutant ${ }^{3>}$ were reported. The $\mathrm{OP}_{1 t}$ phage is a new type mutant and is named the growth temperature mutant.

The writers report the experiments on the interference of $\mathrm{OP}_{1 t}$ to $\mathrm{OP}_{1}$ phage multiplication studied by the single-burst experiment ${ }^{4,103}$ and the one-step growth experiment. ${ }^{(1)}$

\section{Materials}

$\mathrm{OP}_{1}$ phage: A host specific bateriophage of Xanthomonas oryzae, the causal organism of the bacterial leaf blight of rice, and some physiological and biological characters of the phage were reported. ${ }^{15)}$

$\mathrm{OP}_{\text {it }}$ phage: The growth temperature mutant obtained from $\mathrm{OP}_{1}$, and has the same serological and several other characters except in its optimum growth temperature with $\mathrm{OP}_{\mathrm{t}}$.

$X$. oryzae no. 60: Newly isolated strain obtained from $X$. oryzae no. 49

CaViCh medium: Vitamin free casenhydrolysate mediun with $\mathrm{CaCl}_{2}$. The protocol of this medium was reported in the previous paper. ${ }^{15}$. This medium is profitable for both $O P_{1}$ and $O P_{1 t}$ phage multiplications but is not so preferable for the multiplication of $X$. oryzae as the semiartificial medium.

Anti-OP: phage serum: The method to make this was also previously reported. ${ }^{1 i)}$ It reacts with both $O P_{1}$ and $O P_{1}$ phages in equal activity, and inactivates them with the same inactivation constant.

\section{METHOD}

The single-burst experiment is the method with which the reproduced phages from each infected single bacterial cell are assayed quantitatively. If two kinds of phages attack a bacterial cell simultaneously or unsimultaneously, the interference, if present, between both phages in the same host cell will be cleared by this method. The 
principal of this method is to divide the phage infected bacterial suspension to the test tube-growing tube 2 in Protocol 1-, before bacterial lysis takes place, so that each tube will contain, on the average, less than one cell of the infected bacteria. After the burst of all infected bacteria in each tube under definite environmental condition, the produced phage progenies are quantitatively assayed by usual plaque count method.

The procedures of the single-burst experiment used in this experiment are indicated in Protocol 1 and 2.

Protocol 1

Protocol of single-burst experiment (1)

1. Adsorption tube:

$\mathrm{OP}_{1}$ phage suspension

$\left(2.0 \times 10^{6} / \mathrm{ml}\right.$.)

$\mathrm{OP}_{\mathrm{tu}}$ phage suspension

$\left(3.3 \times 10^{7} / \mathrm{ml}\right.$. $)$

Bacterial suspension

$\left(5,0 \times 10^{5} / \mathrm{ml}\right.$.)

2. Serum tube: $\Lambda$ nti-phage serum

3. Dilution tube 1: CaVfCh medium

4. Dilution tube 2: $\mathrm{CaVfCh}$ medium

5. Growing tube 1: $\mathrm{CaVfCh}$ medium

6. Growing tube 2: 50 tubes

7. Plating for plaxue making

8. Change of the incubation tomperature

9. Plaque counting

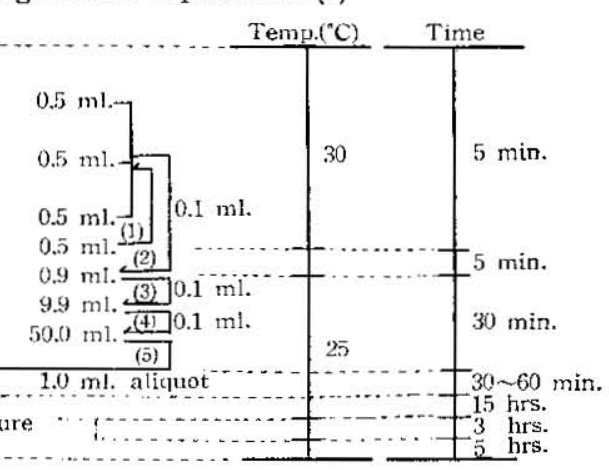

Protocol 2

Protocol of single-burst experiment (2)

1. Adsorption tube:

$\mathrm{OP}_{1}$ phage suspension

$\left(2.0 \times 10^{6} / \mathrm{ml}\right.$.)

$\mathrm{OP}_{\mathrm{It}}$ phage suspension

$\left(3.3 \times 10^{7} / \mathrm{ml}\right.$.)

Bacterial suspension

2. Serum tube: Anti-phage serum

3. Dilution tube 1: $\mathrm{CaVfCh}$ medium

4. Dilution tube 2: $\mathrm{CaVfCh}$ medium

5. Growing tube 1: $\mathrm{CaVfCh}$ medium

6. Growing tube $2: 50$ tubes

7. Plating for plaque making

8. Change of the incubation temperature

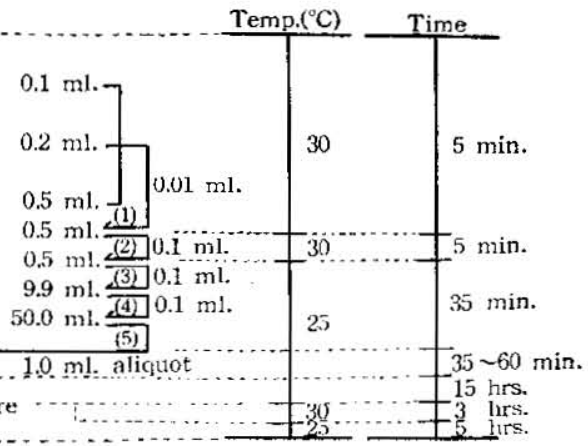

The method used for the one-step growth experiment of $O P_{1}$ and $\mathrm{OP}_{1 t}$ phages is as Protocol 3.

The discriminating method of $\mathrm{OP}_{1}$ from $\mathrm{OP}_{u}$ phage by plaque morphology is as follows.

$\mathrm{OP}_{1}$ phage forms clear plaques at $25^{\circ} \mathrm{C}$. or $30^{\circ} \mathrm{C}$. on $X$. oryzae no. 49 (Plate , figs. 1 et 3), while it forms indistinct plaques at $35^{\circ} \mathrm{C}$. (Plate 
Protocol 3

Protocol of one-step growth experiment

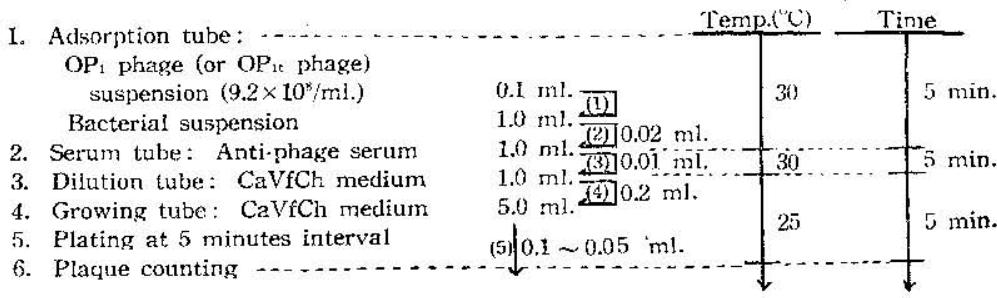

1, fig. 5) Namely, $X$. oryzae no. 49 cells infected with $O P_{1}$ phage are lysed prefectly under these temperatures unless at $35^{\circ} \mathrm{C}$. While $\mathrm{OP}_{1}$ phage forms clear plaques at $25^{\circ} \mathrm{C}$., and cannot at $30^{\circ} \mathrm{C}$. The ability of these phages to lyse the infected bacteria might be depressed by some unknown reasons under such high temperatures.

After plating the mixture of $\mathrm{OP}_{1}$ and $\mathrm{OP}_{1 t}$ phages by usual method, and placing the culture plate successively at $25^{\circ} \mathrm{C}$. (15 hrs.), $30^{\circ} \mathrm{C}$. $(3$ hrs.) and $25^{\circ} \mathrm{C}$. (several hrs.), clear rings will appear in every plaque of $\mathrm{OP}_{1:}$ phages on account of lysis inhibition of the infected bacteria under $30^{\circ} \mathrm{C}$., while there are normal plaques in the case of $\mathrm{OP}_{1}$ phages. By the presence or absence of the rings in plaques, $\mathrm{OP}_{1}$ and $O \mathrm{P}_{1}$ phages are distinguishable from each other easily (Plate, figs. 2 et 4).

If the plate of the bacteria infected alone with $\mathrm{OP}_{1}$ phages is incubated successively at $25^{\circ} \mathrm{C}$, $35^{\circ} \mathrm{C}$. and $25^{\circ} \mathrm{C}$. each under the appropriate period the plaques having clear rings will appear as when $\mathrm{OP}_{1 \text { t }}$ infected bacteria is incubated at $25^{\circ} \mathrm{C}$. $30^{\circ} \mathrm{C}$. and $25^{\circ} \mathrm{C}$. successively. These are based on the fact that both phages differ from each other only phenomena in their optimum growth temperatures.

\section{Results}

The result obtained by conforming to Protocol 1 is showed on the table of Result 1.

Result 1

Result of single-burst experiment

\begin{tabular}{|c|c|c|c|c|c|c|}
\hline Tube no. & No. & $\begin{array}{l}\text { of plaques } \\
\mathrm{OP}^{\mathrm{P}}{ }_{1 t}\end{array}$ & Tube no. & $\begin{array}{c}\text { No. } \\
\mathrm{OP}_{1}\end{array}$ & of & $\begin{array}{l}\text { plaques } \\
\mathrm{OP}_{1 t}\end{array}$ \\
\hline$\frac{-\cdots-\cdots}{1}$ & 0 & {$\left[\begin{array}{lll}1 & \cdots\end{array}\right.$} & 6 & 0 & & 22 \\
\hline 2 & 15 & 9 & 7 & 2 & & 32 \\
\hline 3 & 20 & 14 & 8 & 4 & & 24 \\
\hline 4 & 6 & 9 & 9 & 2 & & 34 \\
\hline 5 & 13 & 19 & 10 & 3 & & 27 \\
\hline
\end{tabular}




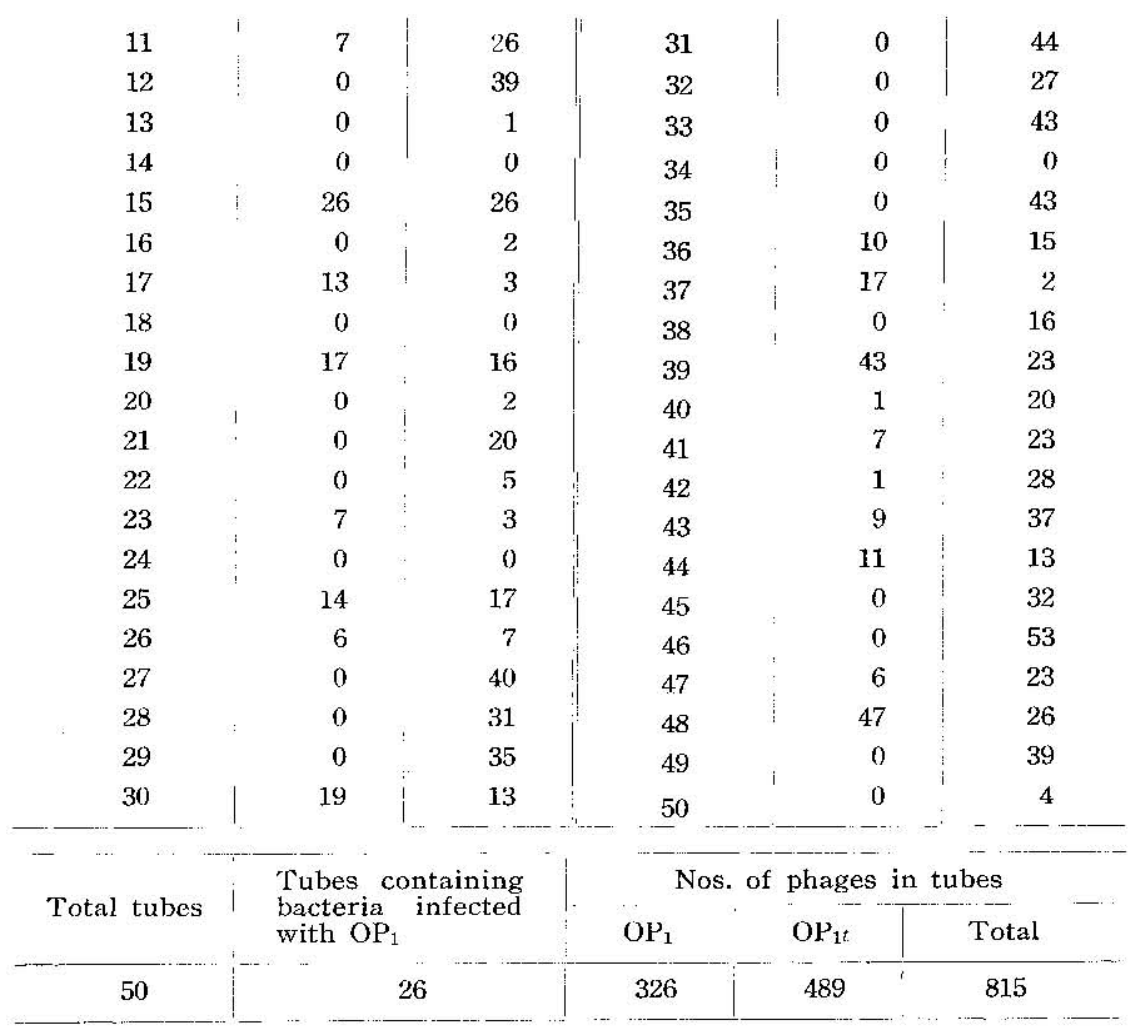

Check (no. of free phages) per $0.1 \mathrm{ml}$. of dilution tube 2 .

\begin{tabular}{c|c|c|}
\hline $\mathrm{OP}_{1}$ & $\mathrm{OP}_{1 t}$ \\
\hline 2 & 6 \\
\hline
\end{tabular}

The result obtained by conforming to Protocol 2 is showed on the table of Result 2.

Result 2

Result of single-burst experiment

\begin{tabular}{c|r|r|r|r|r}
\hline \multirow{2}{*}{ Tube no. } & \multicolumn{2}{|c|}{ No. of plaques } & \multicolumn{2}{c}{ Tube no. } & \multicolumn{2}{c}{ No. of plaques } \\
\cline { 2 - 6 } & $\mathrm{OP}_{1}$ & $\mathrm{OP}_{1 t}$ & & $\mathrm{OP}_{1 t}$ & OP $_{1 t}$ \\
\hline $\mathbf{1}$ & 0 & 57 & 6 & 0 & 81 \\
2 & 0 & 85 & 7 & 0 & 81 \\
3 & 3 & 59 & 8 & 0 & 88 \\
4 & 0 & 118 & 9 & 0 & 112 \\
5 & 0 & 70 & 10 & 7 & 120
\end{tabular}




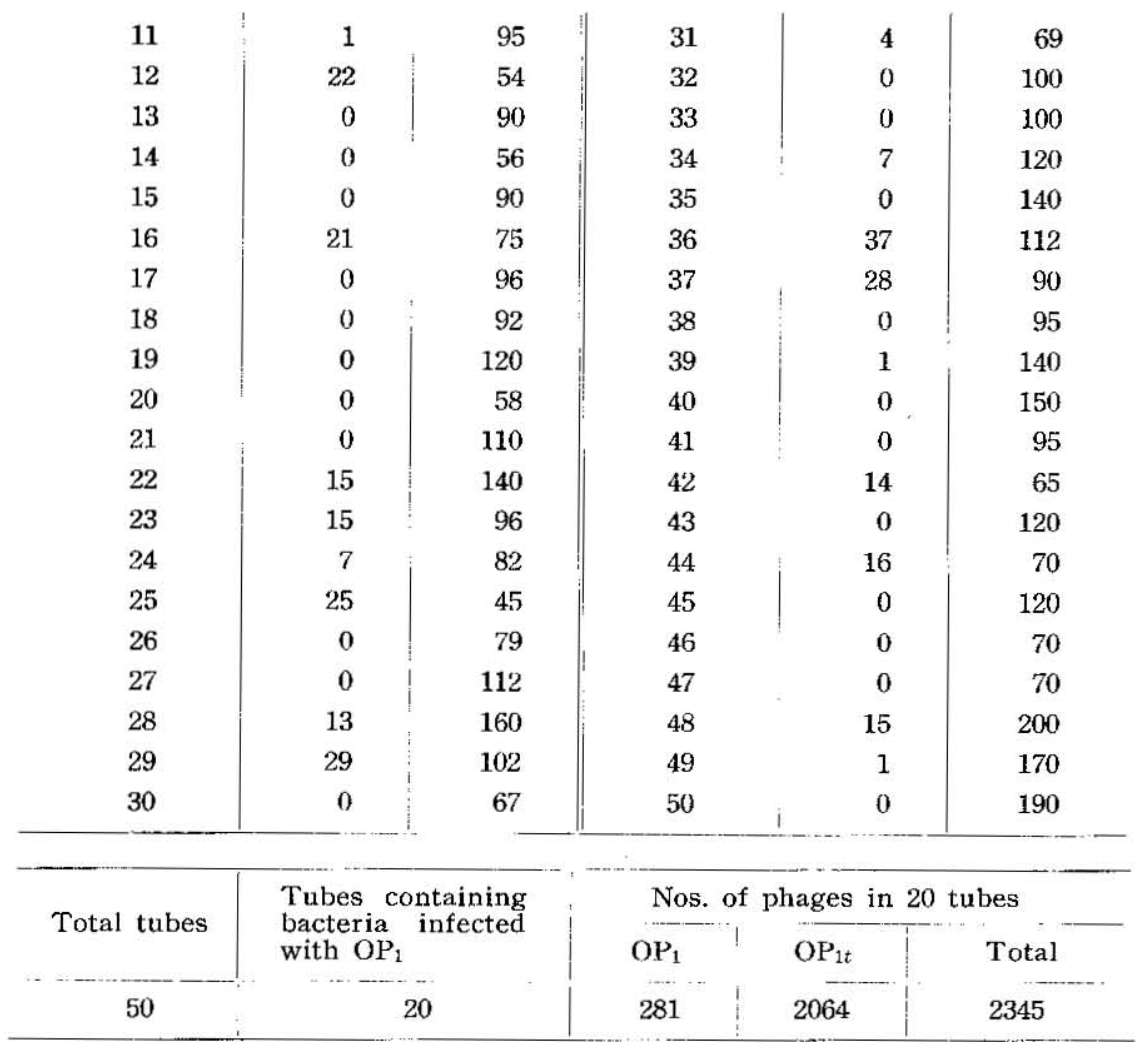

Check (no. of free phages) per $0.1 \mathrm{ml}$. of dilution tube 2 .

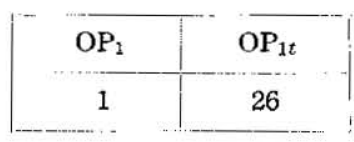

The multiplication formulae of $\mathrm{OP}_{1}$ and $\mathrm{OP}_{1 t}$ phages on $X$. oryzae no. 60 resulting from one-step growth experiment conforming Protocol 3 are given in Result 3 .

Result 3

Result of one-step growth experiment under $25^{\circ} \mathrm{C}$.

\begin{tabular}{c|c|c|c}
\hline & $\begin{array}{c}\text { Latent period } \\
\text { (min.) }\end{array}$ & $\begin{array}{c}\text { Rise period } \\
\text { (min.) }\end{array}$ & Average burst size \\
\hline OP $_{1}$ & 45 & 20 & $25(22-28)$ \\
OP $_{1 \mathrm{t}}$ & 40 & 20 & $25(22-28)$ \\
\hline
\end{tabular}




\section{Discussion}

As stated in the introduction, the interference phenomena between two kinds of phages on the site of reproduction are different according to whether the phages are related or not. When serologically or morphologically related phages attack simultaneously the same host cell, both phages will penetrate and multiply accompanied with some recombinations.

$\mathrm{OP}_{t}$ is the phage derived from the wild type $\mathrm{OP}_{1}$ and is related to the latter with the exception of its optimum growth temperature. It will be expected therefore that simultaneous penetration and multiplication of both two phages in the same host cell will occur when they are inoculated simultaneously. Protocol 1 is the single-burst experiment carried out with the expectation to confirm the existence of above phenomena and to confirm the possibility of alternation of phage reproducing ability of the double infected bacteria with that of the simple infected bacteria.

The distribution pattern of infected bacteria to 50 growing tubes in Result 1 is discussed with Poisson's distribution.

$$
P(r)=\frac{n^{r} \cdot e^{-n}}{r !}
$$

$P(r)$ : Proportion of tubes containing bacterial cells infected with phages in number $(r)$.

$n$ : Average number of infected bacteria per tube.

The following results were obtained with $\mathrm{OP}_{\mathrm{I}}$ phage.

\begin{tabular}{|c|c|c|c|}
\hline & & No. of tubes $(50 \cdot P)$ & $\begin{array}{l}\text { No. of bacteria infected with } \\
\operatorname{OP}_{1}(r-50 \cdot P)\end{array}$ \\
\hline$P(0)$ & 0.48 & 24 & 0 \\
\hline$P(1)$ & 0.353 & 18 & 18 \\
\hline$P(2)$ & 0.131 & 7 & 13 \\
\hline$P(3)$ & 0.032 & 2 & 5 \\
\hline \multirow[t]{2}{*}{$P(4)$} & 0.006 & 0 & 0 \\
\hline & & & Total \\
\hline
\end{tabular}

where $n=0.74$ because $P(0)=\frac{24}{50}=e^{-n}=e^{-0.74}$

Namely, out of 26 tubes which produced $\mathrm{OP}_{1}$ phage, 18 tubes had contained one infected bacterial cell each, 7 tubes 2,2 tubes 3 , and no tubes were found to contain 4 or more bacterial cells infected with the phage. So, the total number of bacteria infected with $\mathrm{OP}_{7}$ phage in 26 tibes was calculated at 36 . The average burst size of OP, phage 
in this experiment were therefore obtained by dividing 326--total yields of $\mathrm{OP}_{1}$ phages by 36 - -the total infected bacterial number of 26 tubes.

$$
N_{\mathrm{op}_{1}}=\begin{gathered}
326 \\
36
\end{gathered}=9
$$

As to $\mathrm{OP}_{1}$ phage, by dividing total yields of 489 in 26 tubes in Result 1 by total $\mathrm{OP}_{1}$ infected bacteria of 36 , the avcrage burst size was obtained.

$$
N_{\mathrm{p}_{1 t}}=\frac{489}{36}=13.6
$$

Considering it as a whole, 26 tubes containing 36 infected bacteria which produced both $\mathrm{OP}_{1}$ and $\mathrm{OP}_{1 t}$ phages; the total phages produced amounted to 815 . So the average burst size of the mixed phages $(\mathrm{N})$ was calculated as follows:

$$
N=\frac{815}{36}=22.6
$$

These figures are nearly equal to those which were obtained from Protocol 3, Result 3. In other words, there are scarcely any differences on the phage producing ability of the bacteria when the case of mixed infection in compared with that of simple infection.

Protocol 2 is the experiment in which the proportion of the number of $\mathrm{OP}_{1 t}$ phages to that of $\mathrm{OP}_{1}$ is changed. From the table of Result 2 , the average burst size of the bacteria regarding $\mathrm{OP}_{1}$ phage is about 9 which is the same as that in the case of Result 1 obtained from the experiment Protocol 1. In other words, in the case of mixed infection, so far as this experiment in concerned, the rate of phage producing ability of the bacteria is not affected even if the ratio of the particle number of the inoculated phages is changed.

Finally, comparing the refults in the tables of Result 1 and 2 with those of Result 3 , it is reasonable to conclude that the partition in constant proportion to the reproducing ability of the host bacteria of $\mathrm{OP}_{1}$ and $\mathrm{OP}_{1}$, phages, in the case of mixed infection, is due to the difference in the latent periods of both phages.

\section{SUMMARY}

$\mathrm{OP}_{\mathrm{it}}$ phage, one step mutant of $\mathrm{OP}_{\mathrm{t}}$ (Xanthomonas oryzae phage), is found to be a new type mutant. It is called a growth temperature mutant because its optimum growth temperature $\left(25^{\circ} \mathrm{C}\right.$.) differs from that of the wild type $\left(30^{\circ} \mathrm{C}\right.$.) .

When these two phages attack simultaneously the same host baterial cell, they both penetrate and multiply. 


\begin{tabular}{c|cc|c}
\hline & $\begin{array}{c}\text { Latent period } \\
\text { (min.) }\end{array}$ & $\begin{array}{c}\text { Rise period } \\
\text { (min.) }\end{array}$ & Average burst size \\
\hline $\mathrm{OP}_{1}$ & 45 & 20 & $25(22-28)$ \\
$\mathrm{OP}_{1 t}$ & 40 & 20 & $25(22-28)$ \\
\hline
\end{tabular}

The phage producing potency of the cell is divided not in accordance with the different multiplicity of the inoculated phages but with their faculties or reproducing speed and the cell released both types of phage progenies in a definite proportion.

Scarcely any difference on the average burst size between the case of mixed infection and that of simple infection is found.

\section{BIBLIOGRAPHY}

1. Adams, M. H. Method in Medical Research, 2, 1-73, 1950.

2. Adams, M. H. and Lark, G. Jour. Immunol., 64, 335-347, 1950.

3. Anderson, T. F. Jour. Bact., 55, 651-658, 1948.

4. Burnet, F. M. British Jour. Exp. Path., 10, 109-115, 1929.

5. Delbrück, M. and Luria, S. E. Arch. Biochem., 1, 111-14I, 1942.

6. Delbrück, M. Jour. Bact,, 50, 151-170, 1945.

7. Doermann, A. H. and Hill, M. B. Genetics, 38, 79-90, 1953.

8. Dulbeccu, R. Genetics, 34, 126-132, 1949.

9. Dulbecco, R. Jour. Bact., 63, 209-217, 1952.

10. Ellis, E. L. and Deibrück, M. Jour. Gen. Physiol., 22, 365-384, 1939.

11. Foster, R. A. C. Jour. Bact., 56, 795-809, 1948.

12. Hershey, A. D. Genetics, 31, 620-640, 1946.

13. Luria, S. E. Genetics, 30, 84-99, 1945.

14. Matsui, C. Sci. Bull. Fac. Agr. Kyushu Univ., 14, 51-56, 1953.

15. Wakimoto, S. Sci. Bull. Fac. Agr. Kyushu Univ., 15, 115-160, 1955.

16. Weigle, J. J. and Delbrück, M. Jour. Bact., 62, 301-318, 1951. 


\section{Explanation of Plate 1}

Fig. 1. Plaques formed by $\mathrm{OP}_{1}$ phages, incubated for $15 \mathrm{hrs}$. at $30^{\circ} \mathrm{C}$.

Fig. 2. Plaques formed by $\mathrm{OP}_{1 t}$ phages, incubated for $15 \mathrm{hrs}$. at $25^{\circ} \mathrm{C}$., $3 \mathrm{hrs}$. at $30^{\circ} \mathrm{C}$. and $3 \mathrm{hrs}$. at $25^{\circ} \mathrm{C}$. successively.

Fig. 3. Plaques formed by $\mathrm{OP}_{1}$ phages, incubated for $15 \mathrm{hrs}$. at $25^{\circ} \mathrm{C}$, $3 \mathrm{hrs}$. at $30^{4} \mathrm{C}$. and $3 \mathrm{hrs}$. at $25^{\circ} \mathrm{C}$. successively.

Fig. 4. Plaques formed by $O \mathrm{P}_{1}$ mixed with $\mathrm{OP}_{1 t}$ phages, incubated for $15 \mathrm{hrs}$, at $25^{\circ} \mathrm{C}$., $3 \mathrm{hrs}$. at $30^{\circ} \mathrm{C}$. and $3 \mathrm{hrs}$. at $25^{\circ} \mathrm{C}$. successively. These plaques with rings on the upper left side are formed by $\mathrm{OP}_{1}$. While the others are formed by $\mathrm{OP}_{1}$.

Fig. 5. Plaques formed by $\mathrm{OP}_{1 t}$ phages, incubated for $15 \mathrm{hrs}$. at $30^{\circ} \mathrm{C}$.

Fig. 6. Plaques formed by $\mathrm{OP}_{1 t}$ phages, incubated for $10 \mathrm{hrs}$. at $30^{\circ} \mathrm{C}$. and $5 \mathrm{hrs}$. at $25^{\circ} \mathrm{C}$. successively. 


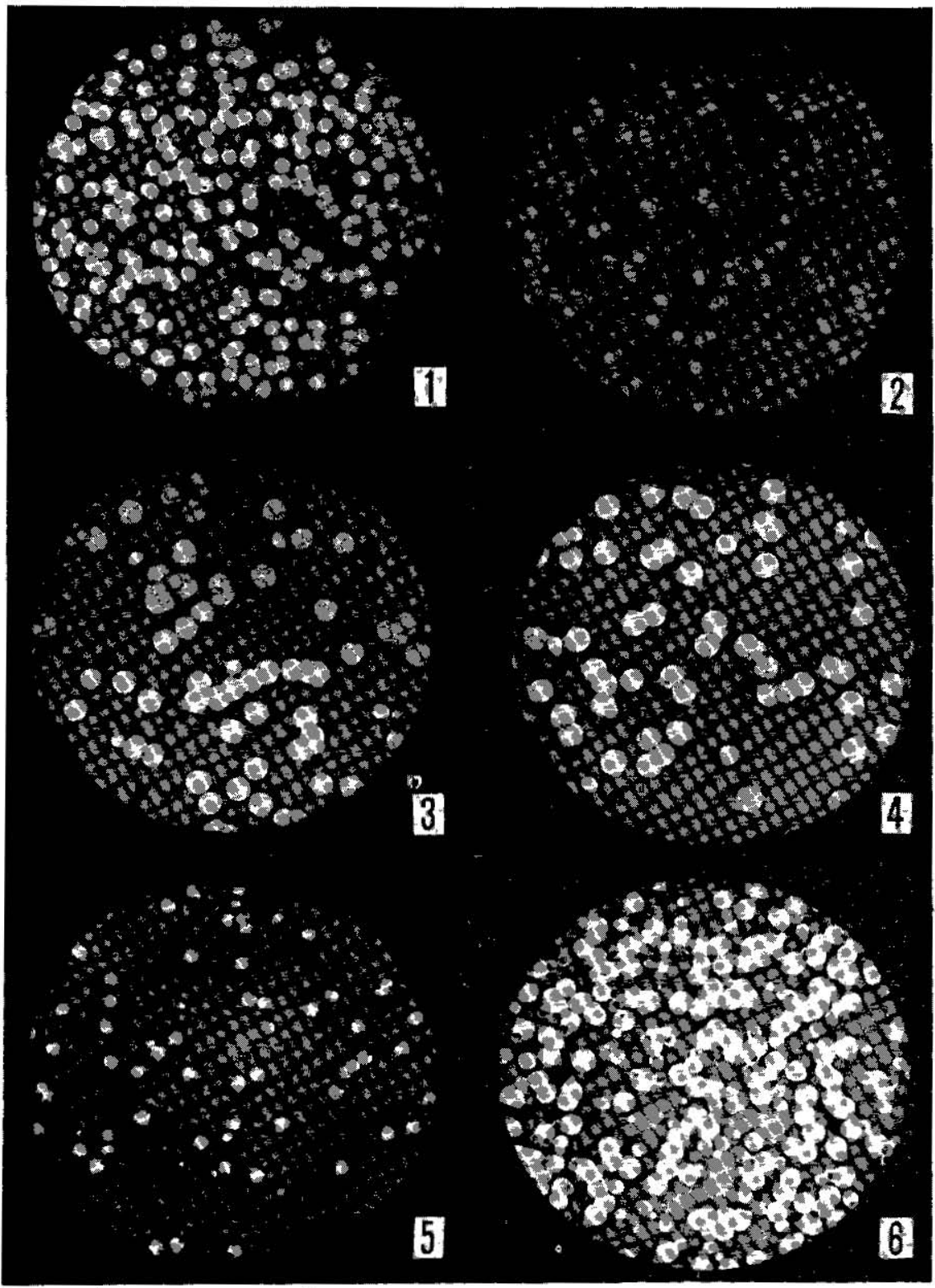

Studies on the multiplication of $\mathrm{OP}_{1}$ phage 